\title{
Mitochondrial genetic transformation via biotechnological approaches or natural competence mechanism: do we have a choice?
}

\author{
M. V. Koulintchenko, A. Dietrich ${ }^{1}$, Yu. M. Konstantinov \\ Siberian Institute of Plant Physiology and Biochemistry, Siberian Branch of the Russian Academy of Sciences \\ 132, Lermontova Str., Irkutsk, Russian Federation, 664033 \\ ${ }^{1}$ CNRS Institute of Plant Molecular Biology, University of Strasbourg \\ 12, General Zimmer Str., Strasbourg, France, 67084 \\ mk100171@yahoo.com; yukon@sifibr.irk.ru
}

Regardless quite assertive proofs of horizontal gene transfer into plant mitochondria, the phenomenon existent in many organisms, this field of research still lacks comprehensive information about the mechanism of gene transfer into mitochondria. Up to now, such questions as how nucleic acids traverse mitochondrial membranes and maintain stability in the mitochondrial genome remain the focus of such researches. Circular and especially linear plasmids present in mitochondria of many plant species could be a convinient tool to investigate the mechanisms of mitochondrial membrane DNA transfer and serve as mitochondrial integrative vectors.

Keywords: mitochondrial transformation, DNA import, mitochondrial plasmids, mitochondrial membrane.

The transformation of mitochondria in vivo is a fundamental scientific problem of a significant biomedical and biotechnological interest. However, up to the present, the resolution of this problem is still unachievable. The main complications of mitochondrial transformation are $(i)$ the small size of mitochondria which makes it difficult to deliver DNA inside the organelles by methods which are in use for chloroplast transformation (bioballistic method); (ii) the absence of a relevant gene-reporter, which would allow to select the transformed mitochondria; (iii) the presence of numerous mitochondria population in each cell, which is an obstacle for manifesting the transformed genotype at the level of a whole cell. It is important to mention also that for getting inside the mitochondria, nucleic acids must be transferred through the hydrophobic cellular and mitochondrial membranes. Inside mitochondria the foreign DNA must be maintained at steady level either by autonomous replication or by being incorporated into the high molecular weight mitochondrial DNA (via re-

(C) Institute of Molecular Biology and Genetics, NAS of Ukraine, 2012 combination) and, at last, imported DNA must be expressed and provide some selective advantage of the transformed mitochondria in heteroplasmic population of organelles in whole cell.

The attempts of mitochondrial transfection of eukaryotes have being undertaken throughout the last two and a half decades. Various methods were tested both to deliver DNA into mitochondria and to make the mitochondrial genome to express the introduced genetic material. The methodical approaches of mitochondrial transformation in vivo were such as (1) bioballistics, this method was limited by using budding yeast and Chlamydomonas reinhardtii [1-4]; (2) cell biology approach, when cells deprived of nucleus but carrying mitochondrial DNA with certain traits, were merged with cells without mtDNA [5, 6]; (3) microinjection of recipient cells by mitochondria containing DNA with certain genetic characteristics $[5,7,8]$; (4) co-incubation of mitochondria with $\rho^{0}$ cells $[9,10]$; (5) using of specific carriers: cell incubation with dequalinium particles $[11,12]$ or mitochondriotropic liposomes [4] loaded with DNA; (6) protein transformation, when DNA is 
linked to hybrid protein, consisting of transduction part, which accommodates the mitochondrial transport, and of a TFAM factor [13-15].

The more effective attempts of allogenic DNA transportation into mitochondria are based on the usage of isolated organelles. To deliver DNA into isolated mitochondria in organello, several approaches were tested: (1) translocation of protein-DNA conjugates $[16,17]$ or of PNA-DNA complexes [18] by means of protein mitochondrial transport machinery; (2) electroporation [1923]; (3) bacterial transfection [24]; (4) mechanism of a natural mitochondrial competence [25-27].

It is known that a natural mechanism of mitochondrial RNA molecules transport exists in many eukaryote organisms (review [28]). This RNA, which is necessary for mtDNA replication and expression, is formed as a result of appropriate nuclear genes expression and imported into mitochondria by mechanisms differing for various organisms. Those mechanisms include some elements of protein (for yeast and mammals [29]) or nucleotide (for plants [30]) mitochondrial transport. Plant and trypanosome mitochondria import from cytosol several tRNA absent in mitochondrial genome, mammalian mitochondria import 5S rRNA, the component of RNase P [31].

Using the phenomenon of tRNA ${ }^{\text {Lys }}$ natural mitochondrial transport in yeast, by Kolesnikova et al. [32] it was shown that the import of modified tRNA ${ }^{\text {Lys }}$ into mitochondria of human cell culture manifesting the mitochondrial translation defect MERRF can partially restore mitochondrial functions.

At first, the attempts of DNA delivery into isolated mitochondria were based mostly on using either the protein transport machinery accommodating the transport of nucleic acid through the mitochondrial membrane [17] or the electroporation [19]. Specific genetic constructs, which represented DNA-protein complexes, containing mitochondrial protein signal peptides, were expressed in cytosol in order to transfer DNA into mitochondria via mechanism of protein transport $[18,16]$. The same mechanism was supposed to be involved in transfer of synthetic PNA molecules, combining the features of proteins (chemical link) and of nucleic acids (nucleotide bases).

As a whole, those approaches are difficult enough technically and, as it was shown practically, had little effectiveness in vivo applications. Only in one of the studies, authors [21] showed functionality of the DNA imported into mitochondria with the help of electroporation, namely, transcription and editing of RNA, transcribed from the xenogenic genetic material. In this study, the isolated plant mitochondria were used.

The distinctive features of plant mitochondria are sizes of their genomes, which are several-fold greater than those of other eukaryotes, and the presence of subgenomic molecules and plasmid-like DNAs, replicated autonomously of the main mitochondrial genome (Table). Those particularities allows to assume that plant mitochondria might possess a mechanism of a natural competence to uptake foreign DNA, resembling that of the process in bacterial cells. The preliminary proofs of such a DNA mitochondrial transport mechanism existence in plants were gained by using of bacterial vectors as both vehicles and templates in the system of mitochondrial DNA and RNA synthesis [58, 59]. Further studies showed that mitochondria, isolated not only from various plant species (potato, maize, cauliflower, tobacco cell suspension culture), but also from mammals (rat liver, human cell cultures) are capable to import double-stranded linear DNA molecules of a reasonable size $(<10 \mathrm{~kb})$ via an active mechanism, nonspecific to DNA sequence $[25,26]$. It was shown that foreign genetic material, namely $g f p$ gene, constituting part of the construct based on the maize mitochondrial plasmid and controlled by mitochondrial regulatory sequences, could be expressed and to serve as a template for DNA synthesis. The presence of the mitochondrial regulatory sequences in the construct was critical both for DNA and for RNA synthesis.

In study [60], authors obtained proofs of imported foreign DNA integration into potato mitochondrial genome via mechanism of homologous recombination. It was established that (1) the gene-reporter can be integrated into mitochondrial genome without duplications and deletions; (2) recombination occurs at regions, flanking the gene-reporter, homologous to mitochondrial genome; (3) the exchange of homologous sequences takes place at the range of $0.5-0.6 \mathrm{~kb}$ in regions flanking the gene reporter; (4) recombination process does not require strict homology between the integrated sequence and the mitochondrial DNA. In studies $[61,62]$ it was also shown that the imported DNA could serve as a 
Plant mitochondrial plasmids

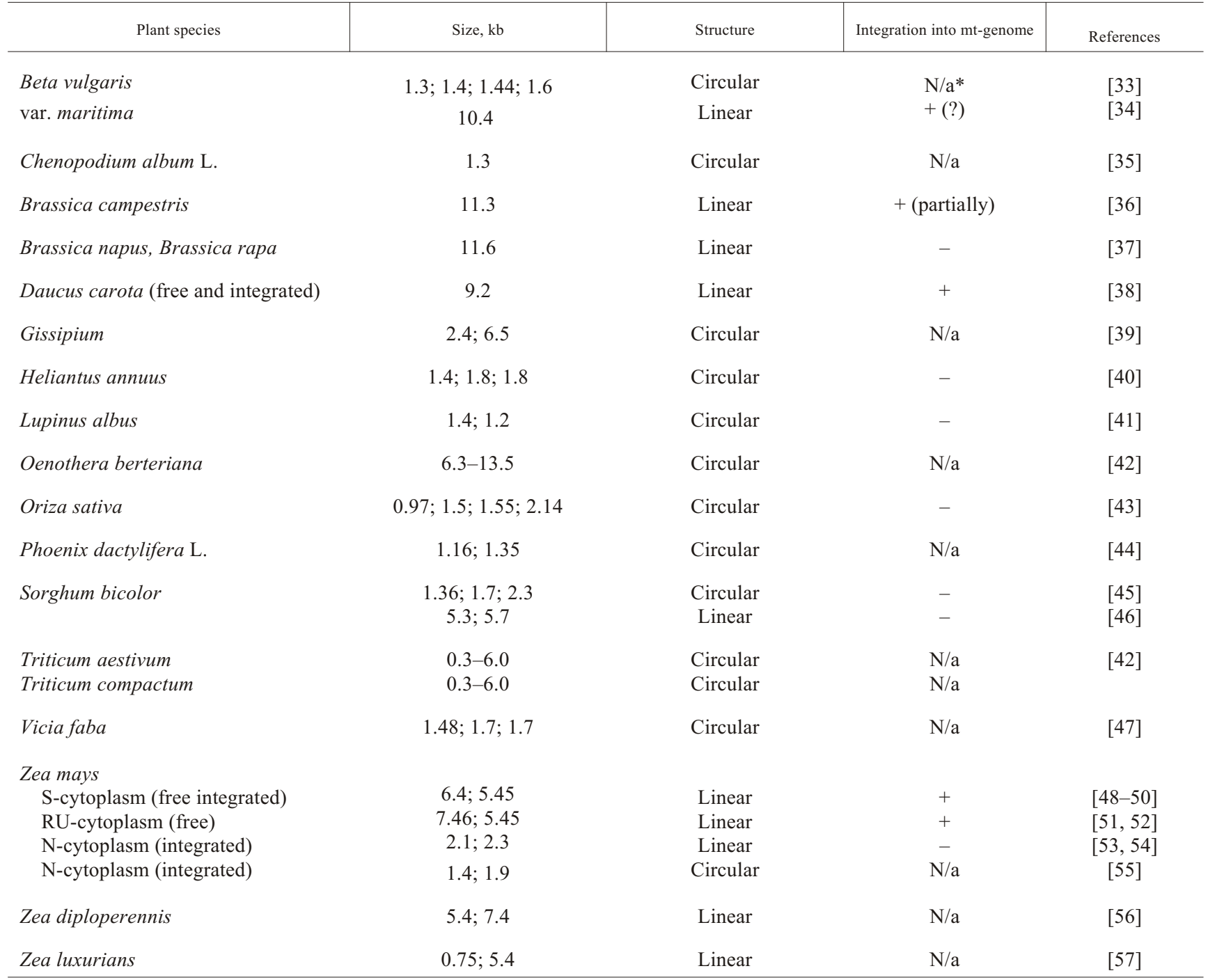

$* \mathrm{~N} / \mathrm{a}-$ not available.

template for repair system in mitochondria isolated both from plants and mammals.

The mechanisms of the DNA import into mitochondria isolated from plants and mammals apparently are differing. For the import of DNA into plant mitochondria it was shown the participation of two mitochondrial membrane proteins, mitochondrial porin (or VDAC, voltage dependent anion channel) in the outer membrane and adenine nucleotide translocase (ANT) in the inner membrane [25]. The functionality of VDAC in DNA import was confirmed as well for the mitochondria of mammals [26] and yeast [63] but, at the same time, the inhibitors and the effectors of the ANT did not influence the process of DNA transfer in the mitochondria of these or- ganisms. So, the DNA transport into mammalian mitochondria is more similar with that of existing in yeast rather than in plants.

In previous studies, where DNA molecules of sizes less than $10 \mathrm{~kb}$ (the main substrate was the mitochondrial plasmid of $2.3 \mathrm{~kb}$ from Zea mays [54]) were used as import substrates, it was shown that the import into mitochondria isolated both from plants and mammals has no specificity concerning the DNA sequence [25, 26]. For plant mitochondria it was established that (1) DNA import does not depend on nucleotide sequence of the imported molecule; (2) the import efficiency decreases with increasing of imported DNA molecule size; (3) import of circular DNA molecules is not as effec- 
tive as that of linear molecules; (4) single-stranded DNA is not imported into mitochondria. For the DNA transport into mammalian mitochondria it was shown one discrepancy as compared to the import into plant mitochondria: they could uptake both the double-stranded and the single-stranded DNA. In further study [64] it was established that the DNA import into plant mitochondria is specific with respect to large DNA substrates. For DNA import into plant mitochondria and into mitochondria of human cell culture authors used the linear plasmid from rapeseed mitochondria (Brassica napus L.) with the size $11.6 \mathrm{~kb}$ [37]. This plasmid, like the $2.3 \mathrm{~kb}$ plasmid from Zea mays [54] is characterized by the terminal inverted repeats present at the each end of the molecules. It's known that inside the organelles these repeats are covalently bound to proteins involved in replication and maintaining of the plasmids. It was shown that (1) the efficiency of large DNA molecules import into plant mitochondria depends on molecule sequence; (2) the specificity of DNA import is mediated by the presence of certain elements in their sequence, namely, the terminal inverted repeats at the $5^{\prime}$ and 3 ' end of the molecules. At that, the DNA import efficiency into mammalian mitochondria did depend neither on the DNA molecule sequence, nor on its size.

All those data allows presuming that (1) the DNA import into mitochondria of various taxonomic groups (plants, fungi, mammals) occurs through different mechanisms; (2) the DNA import into plant mitochondria, being specific with respect to substrate sequence and size, might take place via different biochemical mechanisms. Circular and especially linear plasmids present in mitochondria of many plant species could be a convenient tool to investigate the mechanisms of mitochondrial membrane DNA transfer and serve as mitochondrial integrative vectors.

Acknowledgements. The work was financially supported by grants from Russian Fund for Basic Research 12-04-01400, 12-04-01027.

\section{М. В. Кулінченко, А. Дитриш, Ю. М. Константинов}

Генетична трансформація мітохондрій: методичний вибір між класичними біотехнологічними підходами та природною компетенцією органел

\section{Резюме}

Незважаючи на досить переконливі докази існування горизонтального перенесення генів у рослинні мітохондрії, у иій області дослід- жень залишається чимало невирімених питань, зокрема, не відомий молекулярний механізм горизонтального перенесення генів в органели. На сьогодні не до кіния вивчено низку питань як трансмембранного перенесення, так і умов інтеграиї гетерологічної ДНК у мітохондріальний геном виду-реципієнта. Виявлені в мітохондріях багатьох видів вищих рослин кільцеві $і$, особливо, лінійні плазміди, з одного боку, є зручним інструментом для вивчення механізмів трансмембранного перенесення ДНК $i$, з іншого, -можуть слугувати основою для конструювання мітохондріальних векторів інтегративного типу.

Ключові слова: трансформачія мітохондрій, імпорт ДНК, мітохондріальні плазміди, мітохондріальна мембрана.

\section{М. В. Кулинченко, А. Дитриш, Ю. М. Константинов}

Генетическая трансформация митохондрий: методический выбор между классическими биотехнологическими подходами и природной компетенцией органелл

Резюме

Несмотря на достаточно убедительные доказательства существования горизонтального переноса генов в растительные митохондрии, в этой области исследований остается много нерешенных вопросов, в частности, не известен молекулярный механизм горизонтального переноса генов в органеллы. На сегодняшний день не до кониа изучены многие вопросы как трансмембранного переноса, так и условий интеграции гетерологичной ДНК в митохондриальный геном вида-реципиента. Обнаруженные в митохондриях многих видов высших растений кольцевые $и$, в особенности, линейные плазмиды, с одной стороны, являются удобным инструментом для изучения механизмов трансмембранного переноса ДНК и, с другой, -могут служить основой для конструирования митохондриальных векторов интегративного типа.

Ключевые слова: трансформачия митохондрий, импорт ДНК, митохондриальные плазмиды, митохондриальная мембрана.

\section{REFERENCES}

1. Fox T. D., Sanford J. C., McMullin T. W. Plasmids can stably transform yeast mitochondria lacking endogenous mtDNA // Proc. Natl Acad. Sci. USA.-1988.-85, N 19.-P. 7288-7292.

2. Johnston S. A., Anziano P. Q., Shark K., Sanford J. C., Butow R. $A$. Mitochondrial transformation in yeast by bombardment with microprojectiles // Science.-1988.-240, N 4858.-P. 1538-1541.

3. Randolf-Anderson B. L., Boynton J. E., Gillham N. W., Harris E. H., Johnson A. M., Dorthu M. P., Matagne R. F. Further characterization of the respiratory deficient dum-1 mutantation of Chlamydomonas reinhardtii and its use as recipient for mitochondrial transformation // Mol. Gen. Genet.-1993.-236, N 23.-P. 235-244.

4. Remacle C., Cardol P., Coosemans N., Gaisne M., Bonnefoy N. High-efficiency biolistic transformation of Chlamydomonas mitochondria can be used to insert mutations in complex I genes // Proc. Natl Acad. Sci. USA.-2006.-103, N 12.-P. 4771-4776.

5. King M. P., Attardi G. Injection of mitochondria into human cells leads to a rapid replacement of the endogenous mitochondrial DNA // Cell.-1988.-52, N 6.-P. 811-819.

6. King M. P., Attardi G. Human cells lacking mtDNA: repopulation with exogenous mitochondria by complementation // Science.1989.-246, N 4929.-P. 500-503.

7. Pinkert C. A., Irwin M. H., Johnson L. W., Moffatt R. J. Mitochondria transfer into mouse ova by microinjection // Transgenic Res.-1997.-6, N 6.-P. 379-383. 
8. Pinkert C. A., Trounce I. A. Production of transmitochondrial mice // Methods.-2002.-26, N 4.-P. 348-357.

9. Clark M. A., Shay J. W. Mitochondrial transformation of mammalian cells // Nature.-1982.-295, N 5850.-P. 605-607.

10. Katrangi E., D’Souza G., Boddapati S. V., Kulawiec M., Singh $K$. K., Bigger B., Weissig V. Xenogenic transfer of isolated murine mitochondria into human rho0 cells can improve respiratory function // Rejuvenation Res.-2007.-10, N 4.-P. 561-570.

11. D'Souza G. G., Rammohan R., Cheng S. M., Torchilin V. P., Weissig $V$. DQAsome-mediated delivery of plasmid DNA toward mitochondria in living cells // J. Control Release.-2003.-92, N 1-2.-P. 189-197.

12. D'Souza G. G., Boddapati S. V., Weissig V. Mitochondrial leader sequence-plasmid DNA conjugates delivered into mammalian cells by DQAsomes co-localize with mitochondria // Mitochondrion.-2005.-5, N 5.-P. 352-358.

13. Iyer S., Thomas R. R., Portell F. R., Dunham L. D., Quigley C. $K$., Bennett J. P. Jr. Recombinant mitochondrial transcription factor A with $\mathrm{N}$-terminal mitochondrial transduction domain increases respiration and mitochondrial gene expression // Mitochondrion.-2009.-9, N 3.-P. 196-203.

14. Keeney P. M., Quigley C. K., Dunham L. D., Papageorge C. M., Iyer S., Thomas R. R., Schwarz K. M., Trimmer P. A., Khan S. M., Portell F. R., Bergquist K. E., Bennett J. P. Jr. Mitochondrial gene therapy augments mitochondrial physiology in a Parkinson's disease cell model // Hum. Gene Ther.-2009.-20, N 8.-P. 897907.

15. Khan S. M., Bennett J. P. Development of mitochondrial gene replacement therapy // J. Bioenerg. Biomembr.-2004.-36, N 4.P. 387-393.

16. Seibel P., Trappe J., Villani G., Klopstock T., Papa S., Reichmann $H$. Transfection of mitochondria: strategy tomards a gene therapy of mitochondrial DNA diseases // Nucleic Acids Res.1995.-23, N 1.-P. 10-17.

17. Vestweber D., Schatz G. DNA-protein conjugates can enter mitochondria via the protein import pathway // Nature.-1989.-338, N 6211.-P. 170-172.

18. Flierl A., Jackson C., Cottrell B., Murdock D., Seibel P., Wallace D. C. Targeted delivery of DNA to the mitochondrial compartment via import sequence-conjugated peptide nucleic acid // Mol. Ther.-2003.-7, N 4.-P. 550-557.

19. Collombet J. M., Wheeler V. C., Vogel F., Coutelle C. Introduction of plasmid DNA into isolated mitochondria by electroporation. A novel approach toward gene correction for mitochondrial desordes // J. Biol. Chem.-1997.-272, N 8.-P. 5342-5347.

20. Estevez A. M., Thiemann O. H., Alfonzo J. D., Simpson L. T7 RNA polymerase-driven transcription in mitochondria of Leishmania tarentolae and Trypanosoma brucei // Mol. Biochem. Parasitol.-1999.-103, N 2.-P. 251-259.

21. Farre J. C., Araya A. Gene expression in isolated plant mitochondria: high fidelity of transcription, splicing and editing of a transgene product in electroporated organelles // Nucleic Acids Res.-2001.-29, N 12.-P. 2484-2491.

22. Staudinger M., Kempken F. Electroporation of isolated higherplant mitochondria: transcripts of an introduced cox 2 gene, but not an atp6 gene, are edited in organello // Mol. Genet. Genomics.-2003.-269, N 4.-P. 553-561.

23. Yoon Y. G., Koob M. D. Efficient cloning and engineering of entire mitochondrial genomes in Escherichia coli and transfer into transcriptionally active mitochondria // Nucleic Acids Res.2003.-31, N 5.-P. 1407-1415.

24. Yoon Y. G., Koob M. D. Transformation of isolated mammalian mitochondria by bacterial conjugation // Nucleic Acids Res.2005.-33, N 16.-e139.
25. Koulintchenko M., Konstantinov Y., Dietrich A. Plant mitochondria actively import DNA via the permeability transition pore complex // EMBO J.-2003.-22, N 6.-P. 1245-1254.

26. Koulintchenko M., Temperley R. J., Mason P. A., Dietrich A., Lightowlers $R$. N. Natural competence of mammalian mitochondria allows the molecular investigation of mitochondrial gene expression // Hum. Mol. Genet.-2006.-15, N 1.-P. 143-154.

27. Weber-Lotfi F., Ibrahim N., Boesch P., Paulus F., Cosset A., Konstantinov Y., Lightowlers R. N., Dietrich A. Developing a genetic approach to investigate the mechanism of mitochondrial competence for DNA import // Biochim. Biophys. Acta.-2009.1787, N 5.-P. 320-327.

28. Marechal-Drouard L., Weil J. H., Dietrich A. Transfer RNAs and transfer RNA genes in plants // Annu. Rev. Plant Physiol. Plant Mol. Biol.-1993.-44.-P. 13-32.

29. Tarassov I., Entelis N., Martin R. P. Mitochondrial import of a cytoplasmic lysine-tRNA in yeast is mediated by cooperation of cytoplasmic and mitochondrial lysyl-tRNA synthetases // EMBO J.-1995.-14, N 14.-P. 3461-3471.

30. Delage L., Dietrich A., Cosset A., Marechal-Drouard L. In vitro import of a nuclearly encoded tRNA into mitochondria of Solanum tuberosum // Mol. Cell Biol.-2003.-23, N 11.-P. 4000-4012.

31. Magalhaes P. J., Andreu A. L., Schon E. A. Evidence for the presence of $5 \mathrm{~S}$ rRNA in mammalian mitochondria // Mol. Biol. Cell.-1998.-9, N 9.-P. 2375-2382.

32. Kolesnikova O. A., Entelis R. N., Jacquin-Becker C., Goltzene F., Chrzanowska-Lightowlers Z. M., Lightowlers R. N., Martin R. P., Tarassov I. Nuclear DNA-encoded tRNAs targeted into mitochondria can rescue a mitochondrial DNA mutation associated with the MERRF syndrome in cultured human cells // Hum. Mol. Genet.-2004.-13, N 20.-P. 2519-2534.

33. Thomas C. M. The nucleotide sequence and transcription of minicircular mitochondrial DNA's associated with fertile and cytoplasmic male-sterile lines of sugar beet // Nucleic Acids Res.1986.-14, N 23.-P. 9353-9370.

34. Saumitou-Laprade P., Pannenbecker G., Maggouta F., Jean R., Michaelis $G$. A linear $10.4 \mathrm{~kb}$ plasmid in the mitochondria of Beta maritime // Curr. Genet.-1989.-16, N 3.-P. 181-186.

35. Backert $S$. Strand switching during rolling circle replication of plasmid-like DNA circles in the mitochondria of the higher plant Chenopodium album (L.) // Plasmid.-2000.-43, N 2.P. 166-170.

36. Turpen T., Garger S. J., Marks M. D., Grill L. K. Molecular cloning and physical characterization of a Brassica linear mitochondrial plasmid // Mol. Gen. Genet.-1987.-209, N 2.-P. 227-233.

37. Handa H., Itani K., Sato $H$. Structural features and expression analysis of a linear mitochondrial plasmid in rapeseed (Brassica napus L.) // Mol. Genet. Genomnics.-2002.-267, N 6.-P. 797-805.

38. Robison M. M., Wolyn D. J. A mitochondrial plasmid and plasmid-like RNA and DNA polymerases encoded within the mitochondrial genome of carrot (Daucus carota L.) // Curr. Genet.2005.-47, N 1.-P. 57-66.

39. Usupov T. U., Guzalova A. G., Ibragimov A. P. Discovery and characterization of plasmid-like DNA in cotton-plant // Thesis of Seventh Symposium «Molecular mechanisms of genetic processes» of USSR (Moscow, 27-30 March, 1990).-Moscow, 1990.-P. 187.

40. Crouzillat D., Gentzbittel L., de la Canal L., Vaury C., Perrault A., Nicolas P., Ledoigt $G$. Properties and nucleotide sequence of a mitochondrial plasmid from sunflower // Curr. Genet.-1989.-15, N 4.-P. 283-289.

41. Goraczniak R. M., Augustyniak H. Characterization and sequence of lupin mitochondrial plasmid-like DNA // Curr. Genet.-1989.-16, N 5-6.-P. 469-471. 
42. Esser K., Kuck V., Lemke P. A., Osiewaez H. D., Stahl P., Tudzynski $U$. Plasmids of eukaryotes. Fundamentals and applications.Heidelberg: Springer, 1986.-124 p.

43. Shikanai T., Yang Z. Q., Yamada Y. Nucleotide sequence and molecular characterization of plasmid-like DNAs from mitochondria of cytoplasmic male-sterile rice // Curr. Genet.-1989.-15, N 5.- P. 349-354.

44. Benslimane A. A., Hartmann C., Ouenzar B., Rode A. Intramolecular recombination of a mitochondrial minicircular plasmid-like DNA of date-palm mediated by a set of short direct-repeat sequences // Curr. Genet.-1996.-29, N 6.-P. 591-593.

45. Pring D. R., Conde M. F., Schertz K. F., Levings C. S. Plasmidlike DNAs associated with mitochondria of cytoplasmic male-sterile Sorghum // Mol. Gen. Genet.-1982.-186, N 2.-P. 180-184.

46. Chase C. D., Pring D. R. Properties of the linear N1 and N2 plasmid-like DNAs from mitochondria of cytoplasmic male-sterile Sorghum bicolor // Plant Mol. Biol.-1986.-6, N 1.-P. 53-64.

47. Nikiforova I., Negruk V. Comparative electrophoretical analysis of plasmid-like mitochondrial DNAs in Vicia faba and some other legumes // Planta.-1983.-157, N 1.-P. 81-84.

48. Paillard A., Sederoff R. R., Levings C. S. Nucleotide sequence of the S-1 mitochondrial DNA from the cytoplasm of maize // EMBO J.-1985.-4, N 5.-P. 1125-1128.

49. Weissinger A. K., Timothy D. H., Levings C. S., Hu W. W., Goodman, M. M. Unique plasmid-like mitochondrial DNAs from indigenous maize races of Latin America // Proc. Natl Acad. Sci. USA.-1982.-79, N 1.-P. 1-5.

50. Houchins J. P., Ginsburg H., Rohrbaugh M., Dale, R. M. K., Schardl C. L., Hodge T. P., Lonsdale D. M. DNA sequence analysis of a $5.27-\mathrm{kb}$ direct repeat occurring adjacent to the regions of S-episome homology in maize mitochondria // EMBO J.1986.-5, N 11.-P. 2781-2788.

51. O'Brien C., Zabala G., Walbot $V$. Integrated R2 sequence in mitochondria of fertile B37N maize encodes and expresses a $130 \mathrm{kDa}$ polypeptide similar to that encoded by the S2 episome of S-type male sterile plants // Nucleic Acids Res.-1989.-17, N 1.P. 405-422.

52. Kemble R. J., Gunn R. E., Flavell R. B. Classification of normal and male-sterile cytoplasm in maize. II. Electrophoretic analysis of DNA species in mitochondria // Genetics.-1980.-95, N 2.P. 451-458.

53. Bedinger P., de Hostos E. L., Leon P., Walbot V. Cloning and characterization of a linear 2,3 $\mathrm{kb}$ mitochondrial plasmid of maize // Mol. Gen. Genet.-1986.-205, N 2.-P. 206-212.
54. Leon P., Walbot V., Bedinger P. Molecular analysis of the linear 2,3 kb plasmide of maize mitochondria: apparent capture of tRNA genes // Nucleic Acids Res.-1989.-17, N 11.-P. 4089-4099.

55. Smith A. G., Chourey P. S., Pring D. R. Replication and amplification of the small mitochondrial DNAs in a cell suspension of Black Mexican Sweet maize // Plant Mol. Biol.-1987.-10, N 2.-P. 83-90.

56. Timothy D., Levings C. S., Hu W. W. L., Goodman M. M. Plasmid-like mitochondrial DNAs in diploperenial teosinte // Maydica.-1983.-28, N 2.-P. 139-149.

57. Grace K. S., Allen J. O., Newton K. J. R-type plasmids in mitochondria from a single source of Zea luxerians teosinte // Curr. Genet.-1994.-25, N 3.-P. 258-264.

58. Konstantinov Yu. M., Podsosonny V. A., Lutsenko G. N. DNA synthesis in intact maize mitochondria treated by pBR bacterial vector plasmids // Biopolym. Cell.-1989.-5, N 4.-P. 98-102.

59. Konstantinov Yu. M., Podsosonny V. A., Lutsenko G. N. Rivkin M. I. Translocation of bacterial vector plasmids into intact corn shoot mitochondria // Biochemistry (Russian).-1989.-54, N 1.P. $154-158$.

60. Mileshina D., Koulintchenko M., Konstantinov Y., Dietrich A. Transfection of plant mitochondria and in organello gene integration // Nucleic Acids Res.-2011.-39, N 17.-e115.

61. Boesch P., Ibrahim N., Paulus F., Cosset A., Tarasenko V., Dietrich $A$. Plant mitochondria possess a short-patch base excision DNA repair pathway // Nucleic Acids Res.-2009.-37, N 17.P. 5690-5700.

62. Boesch P., Ibrahim N., Dietrich A., Lightowlers R. N. Membrane association of mitochondrial DNA facilitates base excision repair in mammalian mitochondria // Nucleic Acids Res.-2010.38, N 5.-P. 1478-1488.

63. Weber-Lotfi F., Ibrahim N., Boesch P., Cosset A., Konstantinov $Y$., Lightowlers R. N., Dietrich A. Developing a genetic approach to investigate the mechanism of mitochondrial competence for DNA import // Biochim. Biophys. Acta.-2009.-1787, N 5.P. 320-327.

64. Inrahim N., Handa H., Cosset A., Koulintchenko M., Konstantinov Y., Lightowlers R. N., Dietrich A., Weber-Lotfi F. DNA delivery to mitochondria: sequence specificity and energy enhancement // Pharm. Res.-2011.-28, N 11.-P. 2871-2882.

Received 12.01 .12 